\title{
BENTUK MENARA PHINISI UNM MAKASSAR TERHADAP GERAKAN ANGIN DAN ALIRAN UDARA PADA LINGKUNGAN SEKITARNYA DENGAN METODE SIMULASI KOMPUTER
}

\author{
Usman Faharuddin ${ }^{1}$ \\ ${ }^{1}$ Jurusan Arsitektur Universitas Muslim Indonesia
}

\begin{abstract}
Abstrak
Bentuk dan orientasi terhadap arah angin dapat mempengaruhi pola perilaku aliran udara disekitar lingkungannya dan kecepatan angin di tingkat pejalan kaki mengakibatkan pola aliran angin yang kompleks di sekitar gedung. Sementara faktor yang mempengaruhi adalah topografi fisik bangunan serta hubungan dengan lingkungan sekitarnya dan hambatan bangunan lainnya seperti pagar, vegetasi dan lain-lain. Penelitian ini bertujuan untuk mengetahui efektifitas bentuk menara phinisi terhadap pola gerakan kecepatan angin dan aliran udara yang terjadi pada bangunan menara dan lingkungan sekitarnya dengan menggunakan simulasi software Vasari Beta 3. Metode penelitian adalah eksperimen dengan pengukuran langsung dengan anemometer dan simulasi komputer. Simulasi dilakukan dengan membandingkan bentuk-bentuk bangunan menara untuk mengamati efektifitas bentuk menara phinisi terhadap gerakan kecepatan angin dan pola aliran di lingkungan sekitarnya. Hasil penelitian menunjukkan bahwa bentuk menara phinisi sangat efektif dalam menekan gerakan kecepatan angin dengan hasil simulasi $0,98-2,95 \mathrm{~m} / \mathrm{s}$ pada lingkungan sekitarnya sehingga memenuhi standar kenyamanan dalam skala Beaufort 1,6 - 3,3 m/s dengan efek pada manusia.
\end{abstract}

Kata kunci: aliran udara, efektifitas, kecepatan angin, simulasi, lingkungan sekitarnya

\begin{abstract}
The shape andorientationof thewind directionc an affec tthe behavior patterns of air flow around the environment and wind speeds at pedestrian level wind resulted in a complex flow pattern saround the building. While the factors that influenceis the physical topography of the building and the relation ship with the surrounding environment and other building barriers such as fences, vegetation and others. This research aimed to investigate the effectiveness of phinisi tower form against the movement patterns of wind speed and air flow occurring in the tower building and its surrounding environment using the simulation of Vasari Beta 3 software. The research method is experimental with direct measurement using the anemometer and computer simulation. The simulation was conducted to compare the tower forms with the purpose of observing the effectiveness of the tower phinisi forms againts the speed of the wind movement and the air flow pattern in the surrounding environment. The research results revealed that the phinisi tower form was very effective in resisting the movement of wind speed with simulation result value of $0.98-2.95 \mathrm{~m} / \mathrm{s}$ in the surrounding environment, so that it meet the comfort standard in Beaufort scale $1.6-3.3 \mathrm{~m} / \mathrm{s}$ which was effective to human.
\end{abstract}

Keywords: air flow, effectiveness, wind speed, simulation, surrounding environment

\section{PENDAHULUAN}

Kehadiran gedung-gedung tinggi mempengaruhi kecepatan angin pada tingka terendah disekitarnya. Bentuk dan orientasi bangunan terhadap arah angin dapat mempengaruhi pola perilaku aliran udara di sekitar lingkungannya (Lechner, 2007). Adapun faktor yang mempengaruhi pola aliran udara disekitar bangunan adalah topografi, fisik bangunan, hubungan dengan lingkungan sekitarnya dan hambatan bangunan lainnya, pagar, vegetasi dan lain-lain (Geetha\&Velraj, 2012).

Konsep desain dengan sistem penghawaan alami yang memaksimalkan kecepatan angin, selain memperhatikan pergerakan aliran angin, juga melihat pengaruh lingkungan dan bangunan sekitar terhadap aliran angin tersebut (Allard, 1998). Beberapa faktor bangunan dan lingkungan yang berpengaruh adalah posisi bangunan terhadap lingkungan sekitar, orientasi bangunan, tata letak massa bangunan terhadap arah matahari dan arah datang angin.

Simulasi merupakan suatu metode eksperimental dan terpakai untuk menjelaskan perilaku sistem, membangun teori atau hipotesis yang mempertanggungjawabkan perilaku dari sistem yang diamati, memakai teori-teori untuk meramalkan perilaku sistem yang akan datang, yaitu pengaruh yang akan dihasilkan oleh perubahan variabel dan parameter sistem atau perubahan operasinya (Kenkinanti, 2011). Dalam penelitian ini, menggunakan sofware dari Autodesk yaitu Vasari Beta 3 Ecotect Wind Tunnel

Sebagai aturan umum bahwa kecepatan angin meningkat dengan bertambahnya ketinggian (Peter, 2010). Jika diketahui kecepatan angin pada ketinggian tertentu, maka bisa dihitung pada ketinggian yang lain (Satwiko, 2009). Kecepatan angin di tingkat pejalan kaki mengakibatkan pola 
aliran angin yang kompleks di sekitar gedung (Fadl\& Karadelis, 2013). Studi angin pada lingkungan pejalan kaki akibatnya melibatkan studi tentang aerodinamika bangunan pada umumnya (Blocken, 2003).

Untuk memperkirakan potensi energi angin dari site, data angin yang dikumpulkan dari lokasi harus dianalisis dan ditafsirkan secara benar. Pengukuran lapangan umumnya di lokasi prospektif untuk jangka yang lebih pendek. Sistem pengukuran angin moderen memberikan kecepatan angin rata-rata di lokasi selama periode waktu awal. Dalam sepuluh menit rata-rata sudah umum karena sebahagian besar software (program) angin yang standar cukup sesuai dalam menangani waktu sepuluh menit. Selanjutnya data angin jangka pendek dikelompokkan dan dianalisis dengan bantuan model dan software untuk membuat estimasi yang tepat pada energi yang tersedia dalam angin. Data dikelompokkan selama rentang waktu dimana kita tertarik.

Angin juga dapat menyebabkan ketidaknyamanan untuk pejalan kaki jika kecepatan angin sekitar bangunan terlalu tinggi dengan kriteria kenyamanan pejalan kaki didasarkan pada efek angin mekanik tanpa mempertimbangkan kondisi meteorologi lainnya (Shane, 2011). Penelitian bertujuan untuk mengetahui pola gerakan kecepatan angin yang terjadi pada bangunan menara terhadap lingkungan sekitarnya dengan pengaruh kenyamanan untuk pejalan kaki (Tabel 1).

Tabel 1 Efek Angin pada Manusia

\begin{tabular}{|c|c|c|c|}
\hline $\begin{array}{c}\text { Beaufort } \\
\text { No }\end{array}$ & $\begin{array}{c}\text { Keterang } \\
\text { an }\end{array}$ & $\begin{array}{c}\text { Kecepatan } \\
\text { Angin } \\
\mathrm{m} / \mathrm{s}\end{array}$ & Efek Angin \\
\hline 2 & $\begin{array}{c}\text { Angin } \\
\text { Sepoi- } \\
\text { sepoi }\end{array}$ & $1,6-3,3$ & $\begin{array}{c}\text { Angin } \\
\text { terasa di } \\
\text { wajah }\end{array}$ \\
\hline 3 & $\begin{array}{c}\text { Angin } \\
\text { Lembut }\end{array}$ & $3,4-5,4$ & $\begin{array}{c}\text { Rambut } \\
\text { terganggu, } \\
\text { Pakaian } \\
\text { bergoyang, } \\
\text { sulit baca } \\
\text { koran }\end{array}$ \\
\hline
\end{tabular}

\section{BAHAN DAN METODE}

\subsection{Lokasi dan Racangan Penelitian}

Penelitian ini berada pada Kampus I Universitas Negeri Makassar pada koordinat Lintang 119,435 dan Garis Bujur 5,168 yaitu Gedung Menara Phinisi dan bangunan di sekitarnya. Jenis penelitian ini adalah eksperiment dengan simulasi software Vasari Beta 3 Ecotect Wind Tunnel. Pengukuran dan pengumpulan data lapangan dilakukan pada tanggal 9 Februari 2015. Sedangkan pada software diperoleh pada bulan Februari sampai April 2015.

\subsection{Populasi dan Sampel}

Populasi dalam penelitian ini adalah arah dan kecepatan angin dengan pengambilan data pada elevasi ketinggian bangunan menara. Sampel pada penelitian ini adalah melakukan simulasi 8 arah mata angin pada 3 elevasi ketinggian pada bangunan gedung.

\subsection{Bahan}

Bahan-bahan yang digunakan adalah Anemometer untuk mengukur arah dan kecepatan angin dan Meter sebagai bahan pengukuran dilapangan secara langsung serta software Autocad dan Vasari Beta 3 sebagai alat simulasi komputer.

\subsection{Pengumpulan Data}

Penelitian dilakukan dalam 2 tahap, yaitu mengumpulkan data-data berupa gambar bangunan obyek penelitian yaitu data fisik Gedung Menara Phinisi Kampus UNM Makassar serta obyek-obyek bangunan lain di sekitarnya dengan mencari datadata arah dan kecepatan angin tertinggi. Pengambilan data fisik dilakukan selama 2 minggu, dan data-data kecepatan dan arah angin pada siang hari, mulai jam 10.00 hingga 12.00. Langkah berikut adalah membuat obyek-obyek fisik bangunan dengan menggunakan bantuan program Autocad, selanjutnya melakukan eksperimental dan analisis program dengan menggunakan software Vasari Beta 3 , kemudian mengamati proses gerakan angin yang terjadi pada bangunan menara dan sekitarnya. Pengamatan angin dilakukan untuk melihat pola gerakan angin yang terjadi.

Pengukuran dan pengumpulan data lapangan dilakukan dengan mencari posisi arah angin paling tinggi selama satu menit per satu arah mata angin pada ketinggian 1,20 meter. Hasil pengukuran kecepatan angin menunjukkan bahwa rata-rata kecepatan angin adalah 1,90 m/s dengan arah angin dominan dari $180^{\circ}$.

Pengukuran di lapangan dilakukan dengan pengambilan pengukuran data angin pada lantai top floor di gedung B dengan ketinggian 20 meter. Hasil pengukuran kecepatan angin menunjukkan bahwa rata-rata kecepatan angin adalah $2,65 \mathrm{~m} / \mathrm{s}$ dengan arah angin dominan dari $270^{\circ}$.

Hasil yang dapat diambil dari software adalah wind rose yaitu merupakan mawar angin dalam bentuk tabel (ringkasan) atau diagram. Jumlah data angin yang ditunjukkan dalam tabel akan diambil sebagai pengamatan awal (Rahmat, 2009). Adapun kecepatan rata-rata arah angin di Kota Makassar dalam tabel dan gambar wind rose diambil pada bulan Februari hingga April tahun 2015 (Tabel2).

Tabel 2. Kecepatan Angin bulan Februari-April 2015

\begin{tabular}{|c|c|c|c|c|c|c|}
\hline \multirow{2}{*}{$\begin{array}{c}\text { Arah } \\
\text { Angin }\end{array}$} & \multicolumn{6}{|c|}{ KecepatanAngin (m/s) } \\
\cline { 2 - 7 } & $0-1$, & $2-2$, & $2-3$, & $3-4$, & $4-5$, & $5-5$, \\
\hline $\mathrm{N}$ & 0,18 & 0,76 & 1,17 & 1,40 & 1,43 & 1,43 \\
\hline $\mathrm{NE}$ & 0,24 & 1,46 & 2,37 & 2,88 & 3,05 & 3,05 \\
\hline
\end{tabular}




\begin{tabular}{|c|c|c|c|c|c|c|}
\hline E & 0,42 & 2,09 & 5,46 & 8,16 & 8,96 & 9,11 \\
\hline SE & 0,34 & 2,29 & 5,83 & 9,85 & 13,0 & 13,9 \\
\hline S & 0,24 & 1,05 & 2,20 & 3,57 & 7,23 & 7,23 \\
\hline SW & 0,23 & 1,04 & 1,81 & 2,68 & 4,05 & 4,05 \\
\hline W & 0,19 & 0,70 & 1,51 & 2,65 & 4,39 & 4,39 \\
\hline NW & 0,20 & 0,73 & 1,48 & 2,41 & 3,57 & 3,57 \\
\hline
\end{tabular}

\subsection{Analisis Data}

Data yang diperoleh dari hasil penelitian kemudian dilakukan simulasi dengan mengambil data dari hasil pengukuran langsung pada ketinggian 1,20 meter (Gambar 1).

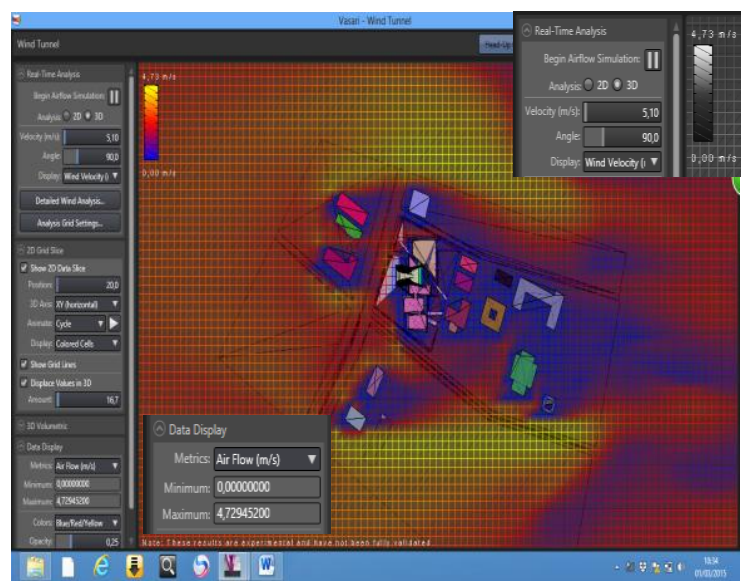

Gambar 1. Simulasi pada Elevasi Ketinggian 1,20 meter.

Pada simulasi ini, kontur warna menggambarkan tingkat velocity angin lingkungan sekitar, berturutturut dari tertinggi dengan kecepatan $4,73 \mathrm{~m} / \mathrm{s}$ berwarna kuning, kecepatan $3,15 \mathrm{~m} / \mathrm{s}$ berwarna merah dan kecepatan $1,58 \mathrm{~m} / \mathrm{s}$ berwarna biru bahkan bisa mencapai $0 \mathrm{~m} / \mathrm{s}$.

Sedangkan data yang diperoleh dari hasil simulasi dengan mengambil data dari hasil pengukuran langsung pada ketinggian 20 meter (Gambar2).

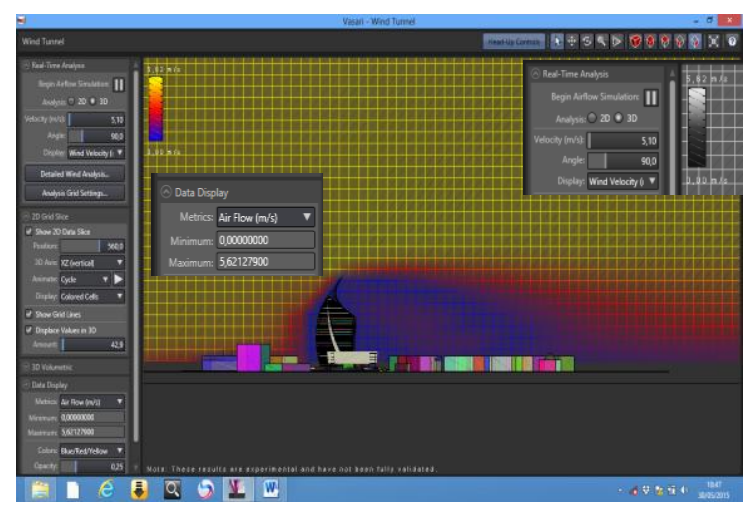

Gambar 2. Simulasi pada Bangunan Menara Phinisi

\section{HASIL PENELITIAN}

Penelitian ini dilakukan simulasi pada ketinggian 1,20 meter, menghasilkan kecepatan angin 0,79-4,73 $\mathrm{m} / \mathrm{s}$, sedangkan simulasi pada ketinggian 20 meter menghasilkan kecepatan angin 0,97-5,82 m/s. Pada pengukuran software dengan kecepatan angin pada bulan februari hingga maret menghasilkan 0,19-4,83 $\mathrm{m} / \mathrm{s}$.

\section{PEMBAHASAN}

Penelitian ini memperlihatkan kecepatan angin semakin meningkat sesuai dengan bertambahnya ketinggian yaitu pada ketinggian 1,20 meter adalah $0,79-4,73 \mathrm{~m} / \mathrm{s}$ dan pada ketinggian 20 meter adalah 0,97-5,82 m/s. Penelitian dengan simulasi komputer menunjukkan bahwa kecepatan angin akan meningkat dengan bertambahnya ketinggian (Satwiko, 2009).

Penelitian ini memperlihatkan bahwa kenyamanan pejalan kaki dengan efek pada manusia pada ketinggian 1,20 meter, terjadi perubahan peningkatan kecepatan angin rata-rata $0,00 \mathrm{~m} / \mathrm{s}$ hingga $1,58 \mathrm{~m} / \mathrm{s}$ untuk setiap satu warna dan dimulai dari warna biru, warna merah hingga warna kuning. Hal ini sejalan dengan hasil dalam tabel tentang efek angin pada manusia di skala Beaufort no 2 yaitu angin sepoi-sepoi dengan kecepatan antara 1,6 m/s hingga $3,3 \mathrm{~m} / \mathrm{s}$ dengan efek hanya terasa di wajah, sedangkan kecepatan angin pada ketinggian 20 meter, terjadi peningkatan kecepatan angin $0,97 \mathrm{~m} / \mathrm{s}$ dengan maksimal $5,82 \mathrm{~m} / \mathrm{s}$ sesuai dengan skala Beaufort no. 3 dengan kecepatan angin antara 3,4 $\mathrm{m} / \mathrm{s}$ hingga $5,4 \mathrm{~m} / \mathrm{s}$, dengan rambut dan pakaian menjadi bergoyang.

\section{KESIMPULAN}

Berdasarkan hasil penelitian dengan menggunakan Simulasi Software Vasari Beta 3, maka dapat ditarik kesimpulan bahwa bentuk Menara Phinisi terhadap kecepatan angin pada lingkungan sekitarnya dengan menggunakan metode simulasi komputer, dapat memenuhi standar kenyamanan pejalan kaki dengan efek pada manusia pada skala Beaufort nomor 2 dan 3. Disarankan dilakukan penelitian lebih lanjut dan lebih akurat dengan menggunakan software lain. Simulasi ini hanya merupakan eksperimental untuk mendapatkan hasil sementara dalam menganalisa pola gerakan angin yang terjadi baik pada bangunan maupun efek yang terjadi di lingkungan sekitarnya.

\section{DAFTAR PUSTAKA}

[1] Allard.(1998). Natural Ventilation in Buildings, A Design Handbook.

[2] Blocken Bert. (2003). Pedestrian Wind Environment around Buildings: Literature Review and Practical Examples. Kasteelpark Arenberg 51, 3001 Leuven, Belgium.

[3] Fadl M.\&Karadelis J. (2013). Cfd Simulation For Wind Comfort And Safety In Urban Area: A Case Study Of Coventry University Central Campus. Department of Civil Engineering, Architecture and Building Faculty of Engineering and Computing. 
[4] Geetha N.B.\& Velraj R. (2012). Passive Cooling Methods for Energy Efficient Buildings With and Without Thermal Energy Storage - A Review. Energy Education Science and Technology, 913946.

[5] Kenkinanti. (2011). Perancangan Algoritma Pengenalan Pola Lapangan Pada Kasus Maze Solving Robot.

[6] Lechner N. (2007). Heating, Cooling, Lighting: Metode Desain Untuk Arsitektur. (S. Sandria na, Penerj.) Jakarta: PT. Raja Grafindo Persada.

[7] Peter A. Irwin. (2010). Wind Issues In The Design Of Tall Buildings. RWDI, Los Angeles Tall Building Structural Design Counci 1 May 7, 2010.

[8]Rahmat Riski. (2009). Mawar Angin. diakses 501-2015, Available from: http://texbuk.blogspot.com/2012/01/kecepatan-

angin-arah-angin-sistem-angin.html

[9] Satwiko P. (2009). Fisika Bangunan. Yogyakarta: Penerbit Andi.

[10] Shane F.(2011). Pedestrian Level Wind Study, 1451 Bathurst Street. GmE 11-008-PLW. 